\title{
AN ANALYSIS OF TEACHER PERFORMANCE APPRAISALS AND THEIR INFLUENCE ON TEACHER PERFORMANCE IN SECONDARY SCHOOLS IN KENYA
}

\author{
Josphat Kagema ${ }^{1}$, Cecilia Irungu ${ }^{2}$ \\ Karatina University, Department of Planning, Administration and Curriculum Development
}

\author{
jkagema@karu.ac.ke
}

First draft received: 08 May 2017 Accepted: 29 July $2018 \quad$ Final proof received: 30 August 2018

\begin{tabular}{l} 
Abstract \\
Every organization has an objective towards optimum performance and the employees are the key \\
drivers in achieving that. It is necessary therefore that the employees' performance reach optimality for \\
the success of the organization which is a primary goal of every organization including learning \\
institutions. The present research investigated the influence of teacher performance appraisals on \\
teacher performance in secondary schools in Kenya. Employing stratified and simple random sampling \\
methods, 46 secondary schools with 460 teachers in two counties in Kenya were taken as samples. \\
The variables under research included teacher remuneration, government policies, school \\
administration, the school environment, and the school curriculum, which were under investigation in \\
form of comparisons, explanations, and relationships on the aspects of teacher motivation to perform \\
well. The research found that teacher appraisals influenced teacher performance. In general, the \\
teachers perceived that government policies are unfavorable to them in terms of career advancement \\
and introduction of the policies in place. The paper concludes with recommendations on application of \\
the appraisal system to motivate teachers and thereby improve the performance of learners. \\
Keywords: Teacher Performance; Appraisals, Motivation; Management \\
To cite this paper (in APA style): \\
Kagema, J., \& Irungu, C. (2018). An analysis of teacher performance appraisals and their influence on \\
teacher performance in secondary schools in Kenya. International Journal of Education, 11(1), 93- \\
98. doi: http://dx.doi.org/10.17509/ije.v11i1.11148 \\
\hline
\end{tabular}

\section{INTRODUCTION}

Educational researchers regard teacher appraisal as an important vehicle for promoting educational quality (Zhang, 2017; Hallinger, Heck, \& Murphy, 2014; Zhang and $\mathrm{Ng}, 2011$ ) which is believed to have the potential to facilitate teachers' professional development and to stimulate instructional improvement. However, critics of teacher appraisal regard it as a mechanical and meaningless exercise (Baker et al., 2010; DarlingHammond et al., 2012). Teacher appraisal becomes a perfunctory ritual activity that is disjointed from the process of teaching improvement and teachers' professional development (Zhang, 2017). Meanwhile, teacher appraisal in Kenyan secondary schools has been mainly inspectorial, achieved through occasional inspection of schools and teachers by school inspectors. However, the head teachers (principals) and heads of academic departments are increasingly playing leading roles in the appraisal of teachers (Odhiambo, 2015) and similar cases replicate in most developing countries.

Performance contracting and performance appraisal systems are part of the broader public sector reforms aimed at improving efficiency and effectiveness in the management of the public service. Performance management in the teaching service existed long before the current drive to reform service delivery in the public sector. However, it is the first time this performance management program is being institutionalized in the teaching service. Crucially, it also underscores the often stated maxim that the teacher is the most invaluable input in the teaching and learning matrix.

The framework for performance management in the teaching service is anchored in the Teachers Service Commission Act (2012) in Section 11 (c) and (f) which makes provisions for monitoring of the conduct and performance of teachers in public learning institutions. In this regard, appraisal and contract reports, therefore, will greatly help the TSC in making key management decisions such as assignment of teachers, deployment to administrative positions, promotion and training programs (Kiplang'at 2016).

The uniqueness of the current annual performance contract and the appraisal program, though, is that performance targets are agreed on beforehand and evaluation standards set in a participatory and 
democratic manner between the appraiser and appraisee. The targets to be achieved are arrived at after taking into account the broad teaching and learning context such as available resources, entry behavior of learners, existing facilities and the general teaching/learning environment. Teachers will be evaluated on how they prepare schemes of work, lessons plan and whether they follow the syllabus. They will also be assessed on the ability to make learning and teaching aids, observance and effective use of time in class, attendance of lessons, staff meetings, participation in co-curricular activities and they will also be evaluated on how they use information technology to advance their skills (Daily Nation, 2016). In a different context, teacher appraisal in schools in Shanghai, China is not a one-off event. Although the procedure for generating appraisal results occurs at the end of each year, data collection activities for appraisal-including lesson observation, student evaluation of teachers and checking teachers' tasks-are conducted throughout the whole year (Zhang \& Ng, 2015).

Once the employees have been selected, trained and motivated and placed on their respective jobs, it becomes essential for the management to conduct performance appraisal to see whether the employees are effective on their jobs or not. By this, the management can also know it has been effective at hiring and placing the employees on their respective jobs. If any problems are identified, steps are taken to communicate with the employee and to remedy them.

Performance appraisal is a process of evaluating an employee's performance of a job in terms of its requirements. It is the systematic, periodic and an impartial rating on an employee's excellence in matters pertaining to his/her present job and to his/her potentialities for a better job (Saleemi, 2011). Aguinis (2009) sees it as a process of identifying, measuring and developing an individual's performance in accordance to organizational goals.

According to Harzing and Pinnington (2011), from a broad perspective, performance appraisals are designed to help organizations draw the best out of their employees, by enabling individual employees to perform at optimal levels. However, the execution of such systems is not always easy and the appraisals frequently do not achieve their goals, with the result that both the employees and their supervisors are often dissatisfied with the system.

Indeed, as Deming (1986) argued, performance appraisals often have the opposite of their intended effect. In other words, if the system is not used properly, evaluations can lead to frustration, anger and reduced motivation levels, rather than motivating employees to perform better. Evaluation of individuals in terms of their job performance is a task requiring a quality of managerial judgement which places a considerable responsibility on the managers involved. It is a task that is delicate as well as complex (Cole, 2004). According to Cole (2004), the most likely reason for the adoption of staff appraisal is to draw attention to present performance in the job in order to reward people fairly and to identify those with potential for promotion or transfer. He further ascertained that appraisal programs are designed not only to provide more systematic control of behavior of subordinates, but also to control the behavior of superiors.

In their comprehensive summary of performance appraisals in the United States of America (USA), Pulakos, Mueller-Hanson and O'Leary (2008) argued that the history of the USA and its fundamentally individualistic culture has had a significant impact on the workplace and performance management practices. Thus, individual performance, accountability and performance-linked rewards, form an integral part of the process. In the USA, appraisals are primarily used for administrative purposes such as awarding merit raises and informing promotion decisions with the use of performance appraisals for developmental purposes remaining rather limited. The realization that the system for teacher appraisal is skewed against favoring the teacher motivated this research and the subsequent recommendations that the study made.

Previously, the teaching service has been under a closed performance appraisal system, where the school head appraised the teacher confidentially. This was shrouded in secrecy as the teacher was not involved in the process. This situation informed the need to review the appraisal process and introduce a more inclusive system. According to Odhiambo (2005), in a study that focused on the state of teacher appraisal in Kenyan secondary schools, there is need for an improved (facilitating) model of teacher appraisal. His findings indicate that teacher appraisal policies and practices in Kenya's secondary schools exhibit weaknesses, which need to be urgently addressed if teacher appraisal has to be used to improve the quality of teaching and education in Kenya.

The TSC says that the use of confidential reports in assessing a teacher's performance and potential has been replaced by a more modern and open assessment system where the teacher participates in his/her performance (Ngeno, Bett and Cheruiyot, 2013).

Assessment of effective teaching at all levels as a function of student learning outcomes has become a major focus of discussion across the country. Ministry of Education, Science and Technology (MOEST) (2005) Sessional paper No. 1 of 2005 reports that teacher promotion has not been based on performance but on qualifications which contributes to the internal inefficiencies. The Kenya Union of Post Primary Teachers (KUPPET) has joined the Kenya National Union of Teachers (KNUT) in rejecting the introduction of performance appraisals for their members. The KUPPET boss has reiterated that teachers must first "be motivated appropriately" before they are given targets (Daily Nation, 2016).

With the limited studies on teacher performance appraisals in Kenya and in response to the concern expressed by previous researchers on this matter, the present research will address the gap by investigating the practice of teacher performance appraisals and how they influence teachers' performance. 


\section{METHOD}

\section{Study Area}

The study was undertaken in two counties that is, Muranga and Kirinyaga counties of Kenya. These areas of study were selected because they had varied types of schools such as county and sub-county schools. The schools captured in the two counties had a balanced representation of the characteristics that of the variables under inquiry involving gender, age, and academic qualification of the teachers, regional diversities, among other factors, including geo-political, economic and social contexts that do reflect the relative distribution in the whole country of Kenya.

\section{Sample and Sampling Techniques}

The research employed stratified and simple random sampling methods to select the sample. The target population was divided into groupings, such as regions of the country and in this case the Counties of Kenya. The researchers targeted two counties of Kenya, namely Kirinyaga and Muranga counties accounting for close to $4 \%$ of the total counties in Kenya. Secondary schools from both counties were selected using the stratified and simple random sampling method. This was to ensure that certain subgroups of the population were represented in the sample in the proportion of their numbers. The researchers identified the different strata of schools that is provincial, district, day schools, boarding schools, and mixed gender schools. The sample of 12 county schools and 34 sub-county schools was selected using stratified and simple random sampling methods hence yielding 46 schools. Table 1 shows a summary of the study's sampling frame.

Table 1. The Sampling Frame

\begin{tabular}{llllll}
\hline Strata & \multicolumn{3}{c}{ County } & \multicolumn{3}{c}{ Sample Techniques } \\
& Muranga & \% Size & Kirinyaga \% Size & \\
\hline Secondary Schools & 23 & 13 & 23 & 21 & Stratified then Simple Random \\
Teachers & 230 & 14 & 230 & 8.7 & Stratified then Simple Random \\
Principals & 23 & 13 & 23 & 21 & Purposive Sampling \\
Heads of Department & 46 & 3 & 46 & 3 & Stratified then Simple Random
\end{tabular}

\section{Instrumentation \\ Questionnaires}

First, the researchers defined the study's objectives to understand the nature of the data required. The items were constructed in an open ended form whereby the respondents were allowed to make any subjective responses. The questionnaires were given to respondents who were expected to read and understand the questions and write down the reply in the space meant for the purpose in the questionnaire itself.

A five item Likert scale was presented for ease of understanding the items. The respondents had to answer the questions on their own. The questionnaires and interview schedules were piloted to examine their clarity and appropriateness for administration ((Kvale, 1996).

The participants in this study responded to the survey. Teachers answered the questionnaires while principals and head of departments responded to an interview schedule. The questionnaire consisted of a sixty-eight item, 5-point Likert -type scale to test the determinants of teacher motivation in curriculum implementation.

In order to test internal consistency reliability, Cronbach's alpha (a) was used. The five subtests of the teacher remunerations, government policies, school administration, and curriculum and job satisfaction) contain eleven, nine, fourteen, eleven and twelve evaluating items, respectively. Table 2 shows Cronbach's alpha for each variable and the number of items measured in the survey instruments (the questionnaires)
Table 2. Cronbach's Alpha for Study Variables and the Number of Items Measured in the Survey Instruments

\begin{tabular}{lll}
\hline Variable & $\begin{array}{l}\text { Cronbach's } \\
\text { alpha }\end{array}$ & $\begin{array}{l}\text { Number } \\
\text { items in the } \\
\text { measure }\end{array}$ \\
\hline Teacher Appraisal & .82 & 15 \\
Teacher Motivation & .85 & 11 \\
\hline
\end{tabular}

\section{Ethical Considerations}

Firstly, the researchers informed the respondents on the nature and purpose of the research, the procedures to be used and expected benefits to the respondents and the Country of Kenya at large. Secondly, key ethical issues relating to research process include privacy of possible and actual participants were followed.

Respondents were accorded voluntary nature of participation and the right to withdraw partially or completely from the research process. Prior and informed consent was requested from them and the researchers maintained high degree of confidentiality of data provided by individuals or identifiable participants and their anonymity. The researchers were honest in search of genuine problems.

The researchers also ensured that the data collection method and instruments were fairly free of anxiety. The researchers further assured the respondents that a discussion of the research findings would be conducted as a way of disseminating the knowledge gathered. Other issues concerned acknowledging all the works that were cited to avoid plagiarism and related malpractices. 


\section{RESULTS AND DISCUSSIONS}

The purpose of the study was to analyze teacher performance appraisals and their influence on teacher performance in secondary schools in Kenya. Data were collected using survey questionnaires from 460 secondary school teachers. The respondents were found in Muranga and Kirinyaga counties of Kenya. The data collected were analyzed thematically and descriptively using descriptive statistics. This was done in line with the five main objectives the study sought to achieve. The data obtained provided information on the variables: teacher remuneration, government policies, school administration, the school environment and the school curriculum which were under investigation in form of comparisons, explanations and relationships on the aspects of teacher motivation.

The majority of the 460 respondents who were targeted for questionnaires responded accordingly such that 440 teachers responded which comprised of the response rate of $96 \%$. This high response rate was so because the researchers made a follow up on all questionnaires in person and the fact that the thesis of the research was a thematic concern to the teachers all over the country.

Empirical studies of teacher motivation in developing countries paint a dismal picture of generally low or declining levels of motivation among formal public school teachers. However, the situation of course varies from country to country. Some countries may face particular threats to teacher motivation while other countries face different or no threats. The teacher performance appraisal recently introduced in Kenya has been criticized for its skewness and bias. Teachers feel that the system lacks objectivity and therefore performance is highly not achieved. To avoid bias in the process, then if an individual has been allowed to have some power of control in the appraisal process then s/he will consider the process as fair (Ju \& Yu, 2005). This concurs with our present study.

This is what basically the present study sought to establish: whether teacher appraisals are indicators of teacher motivation and subsequently teacher performance. Upon analyzing the research questionnaires, it was found out that $63.6 \%$ of the teachers $(\mathrm{N}=274)$ felt that teacher appraisals are unfavorable to teachers (See Table 3). This is because cases were cited of lack of streamlining of policies on teacher appraisal (SD=70.6); policy on promotion and transfers $(S D=55.0)$ and mechanism for teacher recognition of their relative achievement in improved test scores as evidenced in the standardized examinations. The various respondents felt that the government should institute mechanism in enhancing career advancement as well as getting acquainted with the policies in place. This is in consonant with research by Whiting and Kline (2007), that there is tendency of perception that the process could be unfair to the appraise, and hence subjective. This ultimately lowers the staff job satisfaction levels thus affecting the output.

Meanwhile, calculation of the Chi-Square for the same data gives $\chi^{2=} 8.128 ; d f=4 ; p=.0361$ ) (See Table 4). As a result, the $\mathbf{H}_{2}$ stating that there is significant relationship between teacher appraisal and teacher performance was accepted. This indicates that government policies influences teacher motivation that is when the government policies are favorable; it raises the motivation of teachers.

Table 3. Government Policy on Teacher Recruitment and Promotions

Level of satisfaction Policy on teacher recruitment

Policy on teacher promotions

\begin{tabular}{|c|c|c|c|c|c|c|}
\hline & & & Frequency & Percentage & Frequency & Percentage \\
\hline i. & Highly satisfied & & 22 & 5.0 & 19 & 4.3 \\
\hline ii. & Quite satisfied & & 40 & 9.1 & 57 & 13.0 \\
\hline iii. & $\begin{array}{l}\text { Neither satisfied } \\
\text { unsatisfied }\end{array}$ & nor & 100 & 22.7 & 84 & 19.1 \\
\hline iv. & Not satisfied & & 74 & 16.8 & 95 & 21.6 \\
\hline v. & Highly dissatisfied & & 204 & 46.4 & 185 & 42.0 \\
\hline $\mathbf{N}$ & & & 440 & 100.0 & 440 & 100.0 \\
\hline
\end{tabular}

SD (Teacher recruitment) $=67.680 ;$ SD (Teacher promotion and transfer) $=55.804$.

Table 4 Teacher level of Satisfaction by Government Policies

\begin{tabular}{llll}
\hline Variable & $\chi^{2}$ & df & Sign \\
\hline $\begin{array}{l}\text { Government } \\
\text { policies }\end{array}$ & 8.128 & 4 & .0361 \\
\hline
\end{tabular}

The objective under study was once again to analyze teachers' appraisals and their influence on teacher performance in secondary schools in Kenya. The government plays an important role in defining the direction of teacher performance. Government's stated policy is to use assessments not to create competition in the education system but to inform policies and resource allocation, and guide the targeting of support to teachers. These differing approaches are rooted partly in different governance. This concurs with Whyte (1986) who suggests that there is considerable suspicion about the real intentions of the government in suggesting appraisal at the present juncture, and many believe valid, reliable appraisals of teacher competence will be difficult if not impossible to achieve because of the complexity and variety of demands made on teachers in their professional role. The key to effective appraisal therefore is getting the balance right between assessing performance and assisting personal 
development (Elliott, 2015) and the balance will emanate from favorable policies from the government.

Governance reforms in education involve the reallocation of decision-making authority across levels of government. These arrangements affect the roles of parents, teachers, civil servants and politicians at local and national levels. The issues at stake range from financing to school supervision, curriculum development, and teacher recruitment and management agendas. Some countries see testing as a mechanism for promoting an agenda that emphasizes competition, choice and public information to hold service providers to account.

Arguing from the perspective that performance appraisal systems and attendant reforms are aimed at improving efficiency and effectiveness in the management of the public service, the teaching profession cannot be divorced from these dynamics in efforts to wholly adduce a professional entity in it. Teachers' expectations on the processes of appraisal are borne on the fact that it will provide promotion and attendant motivations upon successful appraisals. This study finds that the process of teacher appraisal in Kenya has not structured itself to offer the expected benefits to the appraisees. This therefore qualifies that appraisals per se may have significant impact on teachers' performance if the issues surrounding the welfare of the teacher are not addressed.

Teacher appraisal should be used to motivate staff to improve performance by establishing clear objectives for the future and advising teachers on what is expected of them (Odhiambo, 2005). If appraisal is to be effective, then it has to promotes professional growth and make it beneficial to the majority of teachers who are competent in the classroom (Marzano, 2003). Any kind of appraisal should be undertaken in an objective, fair manner.

\section{CONCLUSION}

This study affirms that when the appraisal system is complicated, employees may not understand it fully and may look at the plan with suspicion. Teacher unions in Kenya are hesitant on the introduction of performance appraisals for their members. The unions feel that TSC is yet to address the issues of poor pay and understaffing in schools, which are key pillars in achieving set targets and feel that teachers must first "be motivated appropriately" before they are given targets. They further felt that TSC could be using these new concepts to introduce new terms of employment to teachers (Daily Nation, January 13, 2016).

Secondly, the appraisal plan should be designed keeping in view the objectives of the appraisal program. The objective of the appraisal program may be either to evaluate current performance on the job or to determine the potential for higher jobs. In some cases, performance appraisal is linked with specific objectives like pay rise, training, promotion and transfer among others. The number of factors to be considered and the data to be collected should be tailor-made to the objective of the appraisal.
Finally, there should be a systematic procedure for redress of grievances arising out of the performance appraisal. The appraisal plan should be valid and reliable. The appraisal should be reviewed with the appraisee. It will help him/her to know where he stands and what further actions he/she should take and also minimize resistance to appraisals.

In the study, admittedly there is a lack of a tool that shows utmost objectivity in the appraisal process. More often than not, the immediate supervisors, namely the heads of departments, deputies and principals are the appraisers. In case of fall-outs with the teacher, the results of appraisal are biased. Therefore, studies should be undertaken to get the principals' expectations and roles in the process. Longitudinal studies should address the effect of appraisals on learners' performance and teacher career acceptance as currently there is inclination towards mobility. The same principles should be inculcated in the teacher training curriculum in Kenya and the world.

\section{REFERENCES}

Aguinis, H. (2009). An expanded view of performance management. In J.W. Smither \& M. London (eds.) Performance Management: Putting research into action (pp. 41-44). San Francisco, CA, US: Jossey-Bass.

Baker E. L., Barton, P. E., Darling-Hammond, L., et al. (2010). Problems with the Use of Student Test Scores to Evaluate Teachers. Washington, DC: Economic Policy Institute.

Borg, W. R. and Gall, M. D. (1989). Educational Research: An Introduction. ( $5^{\text {th }}$ ed.). New York: Longman.

Cohen, D., \& Hill, H. (2000). Instructional policy and classroom performance: The mathematics reform in California. Teachers College Record, 102, 294-343.

Cole, G. A. (2004). Management theory and practice (6 $6^{\text {th }}$ ed.). China: C\&C Offset Printing Co.,Ltd.

Darling-Hammond L, Amrein-Beardsley A., Haertel E., \& Rothstein, J. (2012). Evaluating teacher evaluation. Phi Delta Kappan 93(6), 8-15.

Deming, W.E (1986). Out of the crisis. Cambridge, MA: MIT Press.

DeNisi (eds.), Performance management systems: $A$ global perspective. Glosbal HRM Series. London: Routledge.

Elliott, K. (2015). Teacher performance appraisal: More about performance or development? Australian Journal of Teacher Education, 40(9), 1219..http:/dx.doi.org/10.14221/ajte.2015v40n9.6

Government of Kenya (2012). Teachers service commission act (2012). Nairobi: Government Printer.

Hallinger P., Heck, R. H., \& Murphy, J. (2014). Teacher evaluation and school improvement: an analysis of the evidence. Educational Assessment, Evaluation and Accountability, 26(1), 5-28. 
Harzing, A. W., \& Pinnington, A. H. (2011). International human resource management $\left(3^{r d}\right.$ ed.). Padstow: Tj International Ltd.

Kiplang'at, J. (2016) How TSC will appraise teachers' performance. Daily Nation. Retrieved from http://www.nation.co.ke/ on 13/2/2016.

Kvale, S. (1996). Interviews: An introduction to qualitative research interviewing. Thousand Oaks, CA: Sage.

Marzano, R. (2003). What works in schools: Translating research into action? Alexandria, VA: Association for Supervision and Curriculum Development.

Lu, X.J. \& Yu, W.Z. (2005). Organization fairness structure in organization appraisal, People'S Ergonomics, 4, 24-26.

Ministry of Education, Science and Technology (MOEST) (2005). Sessional Paper No. 1 of 2005. Nairobi: Government Printer.

Monyatsi, P., Steyn, T., \& Kamper, G. (2006). Teacher perceptions of the effectiveness of teacher appraisal in Botswana. South African Journal of Education, 26(2), 215-228.

Ngeno, W. C., Bett, S., \& Cheruiyot, K. (2013). The performance appraisal policy and tools used by the Kenya Teachers Service Commission in Bomet Constituency. International Journal of Humanities and Social Science, 3(16), 229-235.

Odhiambo, G. (2005) Teacher appraisal: the experiences of Kenyan secondary school teachers. Journal of Educational Administration, 43(4), 402-416, https://doi.org/10.1108/09578230510605441

Okumbe, J. A. (2000). Educational management: theory and practice. Nairobi: Nairobi University Press.

Pulakos, E. D., Mueller-Hanson, R. A., \& O'Leary, R.S. (2008). Performance management in the United States, in A. Varma, P.S. Budhwar and A.S. DeNisi (eds.), Performance management systems: A global perspective. Global HRM Series. London: Routledge.

Saleemi, N. A. (2011). Personnel management simplified (Revised \& Updated). Nairobi: ACME Press Kenya) Ltd.

Teachers Service Commission (2005). Code of Regulation for Teachers, Revised 2005, Nairobi.

Teachers Service Commission (2016). The Journey to Performance Management for Teachers. Daily Nation, February 22, 2016. 38-39.

Whyte, J. (1986) Teacher assessment: a review of the performance appraisal literature with special reference to the implications for teacher appraisal, Research Papers in Education, 1(2), 137-163, DOI: $10.1080 / 0267152860010204$

Whiting, H., \& Kline, T. (2007). Testing a model for performance appraisal fit on attitudinal outcomes. The Psychologist Manager Journal 10(2), 127-148

Zhang, X., \& Ng, H. (2015) An effective model of teacher appraisal: Evidence from secondary schools in Shanghai, China, Educational Management Administration and Leadership,
45(2), 196-218. DOI: $0.1177 / 1741143215597234$

Zhang X. F., \& Ng, H. M. (2011). A case study of teacher appraisal in Shanghai, China: in relation to teacher professional development. Asia Pacific Education Review, 12(4), 569-580. 